\title{
Attitudes of Customers towards Islamic Banks in Kuwait
}

\author{
Sayed Al-Hunnayan ${ }^{1} \&$ Abdullah Al-Mutairi ${ }^{2}$ \\ ${ }^{1}$ Arab Open University- Kuwait branch, Kuwait \\ ${ }^{2}$ Gulf University of for Science and Technology, Kuwait \\ Correspondence: Abdullah AL-Mutairi, Gulf University for Science and Technology, Kuwait. E-mail: \\ mutairi.a@gust.edu.kw
}

Received: August 26, 2016

Accepted: September 26, $2016 \quad$ Online Published: October 27, 2016

doi:10.5539/ijbm.v11n11p59

URL: http://dx.doi.org/10.5539/ijbm.v11n11p59

\begin{abstract}
The purpose of this study is to examine the main factors that motivate customers to deal with Islamic banks (IBs) in State of Kuwait and explore items needed by customers to develop IBs services to improve their market position. To achieve these objectives, a self-administered questionnaire distributed among sample of IBs customers from different provinces in Kuwait.

The findings of the analysis showed that customers think that the most important items are the quality of service and low service charges offered by the bank. Moreover, the customers think that the bank mass media is the least important item. The questionnaire also asked customers what IBs need to do in order to develop their services and improve their market position. The participants attached a highest level of importance is to increase the training courses for employees to reach comprehensive employee for non-banking activities and develop practical Islamic mortgages.

The main contribution of current study is that it is difficult to IBs to attract customers by the religion motive only; they need to meet the expectations of prospective customer by delivering better and wide range of services and products.
\end{abstract}

Keywords: Banking facilities, bank selection criteria, customer satisfaction, Islamic banking, religious motives, Kuwait

\section{Introduction}

Islamic Banks (IBs) have witnessed the rapid growth around the world in terms of both volume and quantity. IBs attempt to understand the customers' attitudes towards their products and services to obtain customers' loyalty.

Empirical studies examining the customer's criteria for selecting IBs have shown inconclusive evidence. While some studies reported that religious belief is a main motive to customers in selecting the IBs, other studies provided evidence that religious motives have less influence in deciding the selection of IBs. Thus, the current study will take the State of Kuwait as an example for Muslim country and member in the Gulf Co-operation Council (GCC) market to find out the attitudes of customers towards the five IBs namely Kuwait Finance House (KFH), Boubyan Bank (BB) and Warba Bank (WB), Kuwait International Bank (KIB) and Ahli United Bank (AUB). It also suggests some proposals for improving the services and products of IBs in Kuwait.

The current study is expected to be appreciated by both bankers and customers. For the former, it might assist to realize the choices of the bank customers and attract customers in competitive bank region. For the later, it might enhance the ability of customers to understand the benefits of IBs and improve the criteria considered by customers. Moreover, the findings are assumed to provide some information to the previous literature and develop the limited of empirical studies about Islamic banking industry in the GCC region based on the fact that most previous studies are based on non-GCC countries.

The following sections of the study are a brief review of related literature and previous studies. The third section presents research methodology, the empirical results are offered in section four, and the paper ends with a conclusion. 


\section{Literature Review and Previous Studies}

IBs strive for balancing society and base on the Islamic principles which govern the operations of IBs and known Shariah principles. The first principle is prohibited interest (Riba). In other words, any interest above the original amount of principle which is Riba is forbidden by the Holy Quran and the Sunnah. Karsten (1982) illustrated that Riba is forbidden because it supports the bias for wealth to be collected in few people. IBs are interested to support the social as well as economic outputs of financial transactions (Asutay, 2007). Moreover, IBs have potentials to grow (Awan \& Bukhari, 2011). Accordingly, traditional banks have shifted to Islamic banking processes to gain higher profit (Mamun, 2011).

There are many empirical studies examined the attitudes of customers towards IBs in various countries (Note 1). They found that it is not a religion that attracts customers towards IBs, but it is the products and services which attract the customers towards any business firm. However, the following section reviews in brief these studies.

Kaufman (1967) attempted to explore the elements used by consumers in selecting bank in the United States of America (USA). He discovered that the most significant items are convenient in location, length relationship with customers and service quality provided by the bank. Riggall (1980) added that inexpensive charges of service as well as obtainability of Automated Teller Machines (ATMs) are the main factors applied by consumers.

Erol and El-Bdour (1989) examined the factors in choosing IBs. They pointed out that religious drives are not the only significant ones. Erol et al. (1990) revealed that the fast service, the reputation of the bank and bank confidence are the main factors in the bank selection process for customers. Naser et al. (1999) found that customers in Jordan need fast and efficient services. Naser et al. added that the religious belief is seen as one of the key criteria. Ramadan (2013) used Friedman Test to examine the attitudes of Jordanian customers towards IBs. He found that the three major factors that customers consider while selecting an Islamic bank are friendly personnel, bank reputation and the services price provided by the bank. He also found that the least significant factors are bank location and convenience. Ramadan concluded that religion aspect is not enough to attract customers to IBs; they need to meet the expectations of customers. Kaynak et al. (1991) found that male customers put more importance on bank reputation and fast and efficient services than the female customers. They observed that the bank convenience is the main item for customer under age 40. Kaynak et al. provided evidence that educated customers look at kindness, efficient and quick services and bank location are more significant elements than the uneducated ones.

Haron et al. (1994) compared between the perception of Muslims and non-Muslims towards IBs. They found that there is an agreement between them. They concluded that it is important for the bank success is to understand and satisfy the needs of its customers.

Ahmad and Haron (2002) found that the major factors behind selecting IBs are religious motives, service charges, bank reputation and location. Dusuki and Abdullah (2007) confirmed that financial reputation and quality service offered by the bank are the main items of selecting IBs. Amin (2008) observed that the majority of dealings with Islamic bank are satisfied with the overall service qualities. Haque et al. (2009) demonstrated that the attitudes of customers towards IBs are affected by the quality of services and religious perspective. Marimuthu et al. (2010) stated that customers rely upon bank service charges, friends influence and bank convenience when they select the Islamic bank. They provided evidence that religious motives have no significant influence on the selection of Islamic banking. Loo (2010) observed differences between the attitudes of customers toward IBs between Muslims and non-Muslims. He found that IBs are perceived to lack professional business orientation. Doraisamy et al. (2011) found that customers selected the Islamic bank according to its profit and quality service provided by the bank. Selamat and Abdul-Kadir (2012) explored that religious motive is not a main factor in bank selection but bank customers put high weight on rapid service as well as the bank image and reputation as their primary choice criteria. In contrast, Abduh and Omar (2012) claimed that religious motive is the most important factor before customers decide to select an Islamic bank.

Saleh et al. (2013) added that the accessibility is a significant choice criterion, which includes ATM facility, convenient ATM locations, 24 hours availability of ATM services and speedy service. Nawi et al. (2013) stated that customers depend on some factors when they choose the Islamic bank. These factors are religious motives, service quality provided by the bank and prospect and potentials of Islamic banking. Ismail et al. (2014) observed that some factors behind bank reputation, bank service quality and religious motives. They added media advertisement and social influence factors behind customers selection of IBs.

Rashid and Hassan (2009) examined the bank selection factors that are given higher priorities by groups of customers while selecting any IBs in Bangladesh. They found that non-Islamic factors such as corporal 
efficiency, core-banking services, confidence are given higher weights by majority of the respondents. Rashid and Hassan suggested introducing complete E-Banking solution, increasing advanced marketing efforts and hiring experienced human resources for better Islamic banking activities in Bangladesh. Rashid et al. (2009) pointed out that not only religious factor is being considered by customer while selecting Islamic bank but they also consider other important factors such as efficiency, higher cost benefit, convenient financial transaction system.

Awan and Bukhari (2011) found that most important factors to customers are the quality of service provided by the IBs in Pakistan. They provided evidence that customers rank religious motive is minor leading factor in choosing an Islamic bank. Hamid and Masood (2011) revealed that the shariah principle, fast and efficient services, bank reputation, and product flexibility are the most important factors considered by customers in choosing Islamic mortgages. Rehman and Masood (2012) stated that the most important factors are religious factors and convenient location that customers consider while selecting an Islamic bank. They also found that secure feeling by customer; quality related issues and bank efficiency are other important factors. Khan (2012) found that religious motives have major impact on consumers' behavior towards IBs in Pakistan. Hasan et al. (2012) pointed out that the main causes to customers for selecting IBs are bank profit and the service charges followed by religious purposes and bank service quality. Imtiaz et al. (2013) revealed that customers choose an Islamic bank mostly due to two important factors namely religious motives and banking services. Zulfiqar et al. (2014) pointed out that customers select bank according to bank convenience, quality services provided by the bank and the service charges. Awan and Azhar (2014) provided evidence that religion is considered at lower level in selection criteria of Islamic banking. However, the researchers concluded that customers' satisfaction is increasing day after day and their commitment is strong with the IBs. Tara et al. (2014) stated that the first important criterions are the bank reputation, networking and religious motives. Chebab and Zribi (2012) examined the main elements behind customers moving from a conventional bank to an Islamic bank in Tunisia. They found that the quality of the relationship between the customer and the bank, the quality services provided by the bank and the bank image are the most important factors influencing customer choice.

Abiah and Wabekwa (2012) noticed that IBs are more well-known among young and well-educated people. They recommend that relevant stakeholders should start programs aimed at educating people of the area about Islamic banking. Chikezie and Nwukamaka (2014) examined the customers' attitudes of Moslems and Christians towards Islamic bank's relative advantage in Nigeria. The researchers raised three key selection criteria for IBs namely high level of service efficient, bank reputation and confidentiality. Ramdhony (2013) used standardized questionnaire to examine the criteria of Muslims and non-Muslims for selecting an Islamic bank in Mauritius. He found that there is a difference between the customers of Muslims and non-Muslims regarding to the IBs. Non-Muslims customers think that the most important factors in selecting banks are the service delivery by the bank followed by bank return and convenience and third party influences. Muslims customers consider that third party influences are the greatest factor explained by the model. Ramdhony encouraged IBs attempt to attract non-Muslims to offer rapid and efficient services and encounter their anticipations.

As far as the GCC region is concerned, few studies were undertaken to examine the attitudes of customers towards IBs (see for example, Bahrain: Metawa \& Almossawi, 1998; Almossawi, 2001; Al-Ajmi et al., 2009. UAE: Al-Tamimi \& Abdullah, 2003; Sayani \& Miniaoui, 2013; Saudi Arabia: Hidayat \& Al-Bawardi, 2012; Altwijry \& Abduh, 2013; Kuwait: Naser et al., 2013; AbuAlsoud \& Abdallah, 2013). A concise review of each of these studies is the subject of the succeeding section.

Metawa and Almossawi (1998) examined the customer's perception towards IBs in Bahrain. They found that customer considers Islamic factors followed by cost and benefits in services and influence of the people, and location near to home are the major factors behind selecting Islamic bank. Almossawi (2001) investigated the college students' perception towards IBs. The researcher found that bank's reputation, bank convenience and the availability and location of Automated Teller Machines (ATM) are the main factors behind selecting IBs.

Al-Ajmi et al. (2009) revealed that the two most significant items that affect bank selection are religious motives and social responsibility. They also found that the bank service charges seem to be the third main issue considered in bank selection. Al-Ajmi et al. concluded that IBs customers are aware with the products/services that agree with Islamic Sharia'a.

Al-Tamimi and Abdullah (2003) compared service quality between the Dubai Islamic Bank and the Abu Dhabi Islamic Bank. They found that there is a positive relationship between overall service quality and the SERVQUAL dimensions. They also found that there is no difference between the service quality in the Dubai Islamic Bank and the Abu Dhabi Islamic Bank. Sayani and Miniaoui (2013) examined the factors of bank 
selection for IBs and conventional banks. They found that religious preferences are the most important factor in selection between Islamic and conventional banks. They also demonstrated that bank reputation and expectation of profit on deposits are not determinants of bank selection.

Hidayat and Al-Bawardi (2012) examined the perceptions of non-Muslim expatriates in Saudi Arabia toward Islamic banking products and services. They found that all the respondents are aware of Islamic banking exposures. They also stated that low transaction charges and quality service provided by the bank are the major motives that attract customers to consume Islamic banking services. Altwijry and Abduh (2013) examined the customer satisfaction of IBs customers in Saudi Arabia. They found that the major factors are internet banking, religious motives, accuracy of bank statement and new technology adoption.

Naser et al. (2013) attempted to identify causes behind dealing with the KFH. They found that the main reasons behind dealing with KFH refer to the bank name and reputation, efficient management and the availability of Sharia'h Supervisory Committee. AbuAlsoud and Abdallah (2013) added that bank reputation in regards of abidance with Sharia principles is one of the first five factors but it took last place.

It is appeared that there are limited number of empirical studies have been conducted on the attitudes of customers towards IBS in GCC region. This suggests the need for additional empirical testing. Therefore, the current research is undertaken.

\section{Research Methodology}

The data were collected by self-administered questionnaires as a tool distributed to respondents at 50 different branches from five main IBs namely KFH, BB, WB, KIB and AUB. The questionnaires were distributed to a sample of IBs customers in different provinces in Kuwait. In order to obtain a higher response rate and reduce bias rate, researchers distributed and collected the questionnaire personally and with assistance of moderators, where instructions provided to the participants to complete the survey during their relaxing time.

The questionnaire consists of three parts. The first section contains demographic details such as nationality, age, education, gender and marital status, monthly income and preference Islamic bank. The second part is designed to ask the participants to assess factors that are important to them when selecting Islamic bank. Most of these factors have been drawn from previous related research (Haque et al., 2009; Marimuthu et al., 2010; Doraisamy et al., 2011; Awan \& Bukhari, 2011; Hamid \& Masood, 2011; Rehman \& Masood, 2012; Khan, 2012; Hasan et al., 2012; Selamat \& Abdul-Kadir, 2012; Ismail et al., 2014). The third section was designed to ask the participants about their opinion towards some items to improve the services of IBs.

The questionnaire was reviewed by five university professors specialized in Islamic finance to reach high level of validity and modified according to their suggestions and recommendations. In addition, the questionnaire was piloted among Islamic bank customers as an attempt to be understood by the participants. Consequently, some questions were adapted.

The researchers distributed, on random basis, about 300 questionnaires, 250 out of them were discovered to be suitable for analysis. The data were analyzed by using Statistical Package for the Social Sciences (SPSS) program for windows. To assess the reliability of the collected data, a reliability test was performed. The Cronbach's Alpha for the collected data was 0.80 (Note 2). According to Ramadan (2013) 0.60 or more Cronbach's Alpha value is sufficient to ensure data reliability in such study.

\section{Results of the Analysis}

\subsection{Participants' Background}

The first part of the questionnaire seeks background information about the participants including: nationality, gender, age, level of education, marital status, monthly income, type of work and preference Islamic bank. A summary of the participants' background is presented in Table 1 . 
Table 1. Summary of the participants' background

\begin{tabular}{|c|c|c|c|c|}
\hline & & Frequency & Percent & Cumulative Percent \\
\hline & Kuwaiti & 220 & 88 & 88 \\
\hline \multirow[t]{2}{*}{ Nationality } & Non-Kuwaiti & 30 & 12 & 100 \\
\hline & Total & 250 & 100 & \\
\hline \multirow[t]{3}{*}{ Gender } & Male & 200 & 80 & 80 \\
\hline & Female & 50 & 20 & 100 \\
\hline & Total & 250 & 100 & \\
\hline \multirow[t]{3}{*}{ Marital status } & Single & 40 & 16 & 16 \\
\hline & Married & 210 & 84 & 100 \\
\hline & Total & 250 & 100 & \\
\hline \multirow[t]{5}{*}{ Age } & From 18 - 25 years old & 30 & 12 & 12 \\
\hline & from $25-40$ years old & 150 & 60 & 72 \\
\hline & from $40-50$ years old & 40 & 16 & 88 \\
\hline & More than 50 years old & 30 & 12 & 100 \\
\hline & Total & 250 & 100 & \\
\hline \multirow[t]{7}{*}{ Education level } & Less than high school & 10 & 4 & 4 \\
\hline & High school & 15 & 6 & 10 \\
\hline & Diploma & 50 & 20 & 30 \\
\hline & Bachelor's degree & 150 & 60 & 90 \\
\hline & Master level & 20 & 8 & 98 \\
\hline & Doctorate level & 5 & 2 & 100 \\
\hline & Total & 250 & 100 & \\
\hline \multirow[t]{3}{*}{ Working place } & Public sector & 215 & 86 & 86 \\
\hline & Private sector & 35 & 14 & 100 \\
\hline & Total & 250 & 100 & \\
\hline \multirow[t]{7}{*}{ Monthly income } & Less than $500 \mathrm{KD}$ & 10 & 4 & 4 \\
\hline & from $500-1,000 \mathrm{KD}$ & 20 & 8 & 12 \\
\hline & from $1,000-2,000 \mathrm{KD}$ & 100 & 40 & 52 \\
\hline & from $2,000-2,500 \mathrm{KD}$ & 80 & 32 & 84 \\
\hline & from $2,500-3,000 \mathrm{KD}$ & 30 & 12 & 96 \\
\hline & More than $3,000 \mathrm{KD}$ & 10 & 4 & 100 \\
\hline & Total & 250 & 100 & \\
\hline \multirow[t]{6}{*}{ Preference Islamic Bank } & Kuwait Finance House & 160 & 64 & 64 \\
\hline & Boubyan Bank & 30 & 12 & 76 \\
\hline & Warba Bank & 20 & 8 & 84 \\
\hline & Alhli United Bank & 20 & 8 & 92 \\
\hline & Kuwait International Bank & 20 & 8 & 100 \\
\hline & Total & 250 & 100 & \\
\hline
\end{tabular}

The present study involves a total of 250 participants. The majority of the participants ( 88 percent) are Kuwaitis and the rest (12 percent) are non-Kuwaitis. The table shows that the majority of the participants ( 80 percent) are male, 84 percent of the respondents are married. It also reports that the majority of the respondents deal with KFH. Perhaps the possible explanation refers to the KFH is established in 1977 and becomes a market leader in Islamic banking industry in the Kuwait market. The majority of participants' age (60 percent) is from 25 to 40 years old. Further, it seems that majority of the participants (60 percent) have obtained Bachelor Degree 
followed by participants with College Diploma (20 percent). As for their place of work, more than 85 percent of the participants are government employees, while less than 15 percent are working in private sector. Moreover, it is clear from the table that more than 48 percent of the participants earn $2,000 \mathrm{KD}$ or more per month.

\subsection{Selection Criteria}

Based on the results in Table 2, it is clear that quality of service and low service charges are the most main items for choosing Islamic banking. It ranked the highest mean scores (4.3). This was followed by recommendations from friends and friendly responsive attitude of banking staff (4.2 and 4.1 respectively). Religious motive (shariah principle) seems to be the fifth important factor with the mean scores of 4.1 while the lowest score among the criteria is the advertising in mass media with the mean scores of 2.3.

It is obvious that the most important factors of IBs are the quality of service provided by bank staff and low service charges. It refers to the fact that customers are influenced by responsive attitude of the bank staff. The finding is consistent with the results reached by Hamid and Masood (2011) and Awan and Azhar (2014) and Zulfiqar et al. (2014) who provided evidence that quality of service is the influential factor for the customer in IBs. However, the finding is inconsistent with the results reached by previous empirical studies that reported by Abduh and Omar (2012) who provided evidence that quality of service provided by bank staff play minor influence on customers in selecting IBs in Malaysia.

Table 2. Selecting criteria for Islamic banks

\begin{tabular}{lllll}
\hline$\#$ & Criteria & Mean & SD & Rank \\
\hline 1 & Quality of service & 4.3 & .83 & 1 \\
2 & Low service charges & 4.3 & .84 & 2 \\
3 & Friendly responsive attitude of banking staff & 4.2 & .95 & 3 \\
4 & Recommendations from friends/families & 4.1 & .96 & 4 \\
5 & Religious motives (shariah principle) & 4. & .97 & 5 \\
6 & Convenience in location and car park & 3.9 & 1.08 & 6 \\
7 & Variety of financing options & 3.7 & 1.11 & 7 \\
8 & Privacy \& Confidentiality & 3.5 & 1.15 & 8 \\
9 & Availability of ATM & 3.2 & 1.22 & 9 \\
10 & High profit & 3 & 1.3 & 10 \\
11 & Bank reputation \& image & 2.5 & 1.5 & 11 \\
12 & Mass media & 2.3 & 1.7 & 12 \\
\hline
\end{tabular}

Table 2 also reveals that participants ranked influence of friends and relatives are important components considered by customers for selecting Islamic bank in Kuwait. It refers to the fact that participants are affected by spouses, friends and relatives as their innate religious motivation. Thus, influence by the friends and family is on third priority in the selection criterion of Islamic banking. Moreover, in Moslem societies where parents often live with grown children, their influence can be substantial. The finding is consistent with the results reached by Awan and Azhar (2014) that confirmed family is the most influential group for the consumer in Pakistan. However, the finding is inconsistent with the results reached by Abduh and Omar (2012) that stated friendly personnel is the lowest factor influencing customers in selecting IBs in Malaysia.

Moreover, the table shows that participants ranked religious motives or Shariah principles (prevention of riba) are the most important components considered by customers for selecting an Islamic bank in Kuwait. It might refer to the fact that participants are commitment with Islamic ethical beliefs and practices. Muslims select Islamic banking as an ethical principle because it is prohibited interest that's why they prefer Islamic banking system as compared to conventional banking. Thus, customer focuses on the religious view as benefit. It confirms that religion is an integrated process of values relative to the holly topics, while religiosity is perceived as the level to which beliefs are practiced by individual Islamic principles. The finding is consistent with the results reached by Dusuki and Abdullah (2007) who stated that Islamic bankers should no longer rely upon marketing strategy of attracting religious customers who might only concern about Islamicity of financial product. Erol and El-Bdour (1989) observed that religious causes are not the only item for inviting customers. In addition, Awan and Azhar (2014) noticed that the customers of IBs pay little attention to religious motives when they decide to select Islamic bank in Pakistan. However, the finding is inconsistent with the results reached by previous empirical studies that reported shariah principle is the chief factor that influencing customers in 
selecting IBs such as Hamid and Masood (2011), Rehman and Masood (2012) Imtiaz et al. (2013) in Pakistan.

The analysis demonstrates that participants ranked mass media advertising is the lowest important component considered by customers for selecting an Islamic bank in Kuwait. It might attribute to the fact that IBs in Kuwait are well-known among customers in Kuwait. The finding is consistent with the results reached by Hamid and Masood (2011) who found mass media is less influence on attract customers. However, it is not agreement with earlier studies like Ismail et al. (2014) in Malaysia.

\subsection{Tools for Improving Services and Products of Islamic Banks}

Number of proposals that may improve services and products of IBs in Kuwait are presented in the questionnaire and the customers were requested to provide their level of agreement about each of them. The results of the analysis are reported in Table 3.

Table 3. Tools for developing services in IBs in Kuwait

\begin{tabular}{|c|c|c|c|c|}
\hline \# & Market Share & Mean & SD & Rank \\
\hline 1 & To use comprehensive employee for non-banking activities & 4.4 & .84 & 1 \\
\hline 2 & To develop the training courses for employees. & 4.3 & .85 & 2 \\
\hline 4 & $\begin{array}{l}\text { To establish consultancy unit that assists young graduates in developing small business complying } \\
\text { with Islamic Sharia'h. }\end{array}$ & 4.1 & .93 & 4 \\
\hline 5 & To organize workshops to explain to the public the nature of Islamic financing & 4. & .95 & 5 \\
\hline 6 & $\begin{array}{l}\text { To collaborate with local universities to develop specialized academic programs that lead to degrees } \\
\text { in the areas of Islamic banking and finance }\end{array}$ & 3.9 & 1.0 & 6 \\
\hline 7 & $\begin{array}{l}\text { To become more socially responsible by sponsoring students specializing in the areas of Islamic } \\
\text { banking and finance }\end{array}$ & 3.8 & 1.1 & 7 \\
\hline 8 & To establish an academy of Islamic banking and finance & 3.7 & 1.12 & 8 \\
\hline 9 & To improve the branch network throughout the region & 3.5 & 1.2 & 9 \\
\hline 11 & To embark on more risky products and services & 2.8 & 1.6 & 11 \\
\hline 12 & To harmonize the financial statements & 2.2 & 1.9 & 12 \\
\hline
\end{tabular}

The table shows the customers think that the main significant proposals for developing IBs are increase the training courses for employees and use comprehensive employee for non-banking activities followed by develop practical Islamic mortgages and establish consultancy unit to assist young graduates in run their own business with means 4.4, 4.3, 4.2 and 4.1 respectively.

It is clear that the customers need fast services in IBs. It seems that participants think one desk service saves their time and reflects that the bank's employees have received intensive training courses and work with confident. It is recommended to deliver the service to the customers by phone or even by mail. However, one-step service meets customers' expectations and keeps them coming back to you for service. According to Mirza and Riaz (2012) the training manager is responsible to develop the training programs. Mahat and Ali (2012) explored that the majority of the employees operating in the IBs do not have enough training or knowledge about Islamic banking. Furthermore, Marimuthu et al. (2010) suggested that IBs should hire qualified experts to encourage more innovativeness particularly in dealing with the products and services of IBs. Mamun (2011) suggested that IBs should emphasis on training and education to assure competent human resources and better post financing services.

Khalid and Amjad (2012) encourage IBs to enhance the staff quality and stated that bank managers need to present fast and efficient services with high confidentiality (Selamat \& Abdul-Kadir, 2012). There is a need to e-banking customers since they do not have a time to visit the bank branches (Zulfiqar et al., 2014).

The analysis showed that participants believe that IBs have a social responsibility. One of these responsibilities is to contribute to solve the housing problem in Kuwait. For example, KFH includes some activities to solve housing problem (Zaher \& Hassan, 2001). Other IBs, in UAE and Bahrain, started to provide the market with financial products for housing finance.

The development of the network of links among IBs in the regions leads to more efficient allocation of financial resources across borders and contributes to enhancing global growth prospects (Ahmed, 2010). According to 
Zaher and Hassan (2001) there is a lack of cooperation among Muslim financial institutions.

\section{Conclusion}

In this study, an attempt was made to examine the main items behind selecting Islamic bank by customers and tools to improve their services and products. The study distributed 300 questionnaires, 250 of them were valid for analysis. In order to check the stability of the questionnaire, Cronbach's alpha coefficient was applied where the findings reported the reliability coefficient was above 0.70 .

It is obvious that customers of IBs in Kuwait rank banking selection factors differently. The study showed that the first and the second factors for the Kuwaiti customers in selecting the IBs are quality of service and low service charges. It also demonstrated that friendly responsive attitudes of banking staff and recommendations from friends and families are the third and the fourth main items for the Islamic banking customers in Kuwait respectively. Moreover, the study provided evidence that participants rank religion motives in the fifth position of importance. It seems that there are some customers who are concerned with matters of religious faiths when selecting particular bank.

The analysis showed that there is a need to increase the skills of IBs employees and use comprehensive employee for non-banking activities. The study revealed that IBs have a social responsibility such as solving housing problem in Islamic countries by developing practical Islamic mortgages and enhancing financial products for housing finance.

The comparison study of customer's satisfaction towards the products and services of both Islamic and conventional banking would be appreciated for future study. Moreover, this study was limited to only IBs in Kuwait; future researches might deal with IBs in the GCC region.

\section{Acknowledgments}

This work was supported by a grant from the Arab Open University-Kuwait branch. The authors would like to convey their special tokens of gratitude to the research committee for its support and guidance.

\section{References}

Abduh, M., \& Omar, M. (2012). Islamic-bank selection criteria in Malaysia: An Ahp approach. Business Intelligence Journal, 5(2), 271-281.

Abiah, F., \& Wabekwa, B. (2012). People's perception towards Islamic banking: A field work study in Gombe Local Government Area, Nigeria. International Journal of Business, Humanities and Technology, 2(7), 121-131.

AbuAlsoud, G., \& Abdallah, M. (2013). Customer awareness and satisfaction of Islamic retail products in Kuwait. Research Journal of Finance and Accounting, 4(17), 36-52.

Ahmad, N., \& Haron, S. (2002). Perceptions of Malaysian corporate customers towards Islamic banking products and services. International Journal of Islamic Financial Services, 3(4), 13-29.

Ahmed, A. (2010). Global financial crisis: An Islamic finance perspective. International Journal of Islamic and Middle Eastern Finance and Management, 3(4), 306-320. http://dx.doi.org/10.1108/17538391011093252

Al-Ajmi, J., Abo Hussain, H., \& Al-Saleh, N. (2009). Clients of conventional and Islamic banks in Bahrain: How they choose which bank to patronize. International Journal of Social Economics, 36(11), 1086-1112. http://dx.doi.org/10.1108/03068290910992642

Almossawi, M. (2001). Bank selection criteria employed by college students in Bahrain: An empirical analysis. International Journal of Bank Marketing, 19(3), 115-125.

Al-Tamimi, H., \& Abdullah, A. (2003). Analysing service quality in the UAE Islamic banks. Journal of Financial Services Marketing, 8(2), 119-132. http://dx.doi.org/10.1057/palgrave.fsm.4770112

Altwijry, O., \& Abduh, M. (2013). Customer satisfaction and switching behavior in Saudi Islamic banks: An exploratory study. Journal of Islamic Finance, 2(2), 17-25.

Amin, H. (2008). Choice criteria for Islamic home financing: Empirical investigation among Malaysian bank customers. International Journal of Housing Markets and Analysis, 1(3), 256-274.

Asutay, M. (2007). Conceptualisation of the second best solution in overcoming the social failure of Islamic finance: Examining the overpowering of homoislamicus by homoeconomicus. IIUM Journal of Economics and Management, 15, 167-195.

Awan, A., \& Azhar, M. (2014). Consumer beahvioiur towards Islamic banking in Pakistan. European Journal of 
Accounting Auditing and Finance Research, 2(9), 42-65.

Awan, H., \& Bukhari, Kh. (2011). Customer's criteria for selecting an Islamic bank: Evidence from Pakistan. Journal of Islamic Marketing, 2(1), 14-27.

Chebab, S., \& Zribi, H. (2012). Expected regret and Islamic banking in emerging countries: The case of Tunisia. Journal of Business Studies Quarterly, 3(4), 119-131.

Chikezie, E., \& Nwukamaka, N. (2014). Islamic banking in Nigeria: Perceived relative advantage among religious groups in Anambra State. African Research Review, 8(2), 158-174.

Doraisamy, B., Shanmugam, A., \& Raman, A. (2011). A study on consumers' preferences of Islamic banking products and services in Sungai Petanu. Academic Research International, 1(3), 290-302.

Dusuki, A., \& Abdullah, N. (2007). Why do Malaysian customers patronise Islamic banks? International Journal of Bank Marketing, 25(3), 142-160. http://dx.doi.org/10.1108/02652320710739850

Erol, C., \& Radi, E. (1989). Attitude, behavior and patronage factors of bank customers towards Islamic Banks. International Journal of Bank Market, 7(6), 31-37.

Erol, C., Kaynak, E., \& El-Bdour, R. (1990). Conventional and Islamic bank: Patronage behaviour of Jordanian customers. International Journal of Bank Marketing, 8(5), 25-35.

Hamid, A., \& Masood, O. (2011). Selection criteria for Islamic home financing: A case study of Pakistan. Quality Research in Financial Markets, 3(2), 117-130.

Haque, A., Osman, J., \& Ismail, A. (2009). Factor influences selection of Islamic banking: A study on Malaysian customer preferences. American Journal of Applied Science, 6(5), 922-928.

Haron, S., Ahmad, N., \& Planisek, S. (1994). Bank patronage factors of Muslim and non-Muslim customers. International Journal of Bank Marketing, 12(1), 22-40.

Hasan, S., Subhani, M., \& Osman, A. (2012). Consumer criteria for the selection of an Islamic bank: Evidence from Pakistan. International Research Journal of Finance and Economics, 94. Retrieved from http://mpra.ub.uni-muenchen.de/40384/1/MPRA_paper_40384.pdf

Hidayat, S., \& Al-Bawardi, N. (2012). Non-Muslims' perceptions toward Islamic banking services in Saudi Arabia.

Imtiaz, N., Murtaza, A., Abaas, M., \& Hayat, Kh. (2013). Factors affecting the individual's behavior towards Islamic banking in Pakistan: An empirical study. Educational Research International, 1(2), 106-111.

Ismail, Sh., Azmi, F., \& Thurasamy, R. (2014). Selection criteria for Islamic home financing in Malaysia. International Journal of Business and Society, 15(1), 97-110.

Kaufman, G. (1967). A survey of business firms and households view of a commercial bank. Report to the Federal Reserve Bank of Chicago, Appleton, University of Wisconsin, Madison, WI.

Kaynak, E., Kucukemiroglu, O., \& Odabasi, Y. (1991). Commercial bank selection in Turkey. International Journal of Bank Marketing, 9(4), 30-39.

Khalid, S., \& Amjad, Sh. (2012). Risk management practices in Islamic banks of Pakistan. The Journal of Risk Finance, 13(2), 148-159.

Khan, Sh. (2012). Factors responsible for making consider attitude towards Islamic banking. Arabian Journal of Business and Management Review, 2(1), 136-146.

Loo, M. (2010). Attitudes and perceptions towards Islamic banking among Muslims and non-Muslims in Malaysia: Implications for marketing to baby boomers and X-generation. International Journal of Arts and Sciences, 3(13), 453-485.

Mahat, F., \& Ali, N. (2012). Malaysian bankers acceptance criteria on Islamic financial system. International Journal of Business and Commerce, 1(6), 71-86.

Mamun, M. (2011). Prospects and Problems of Islamic Banking from Bank's Perspective: A study of Bangladesh. 8th International Conference on Islamic Economics and Finance. Center for Islamic Economics and Finance, Qatar Faculty of Islamic Studies, Qatar Foundation, 18-20 December, Doha, Qatar.

Marimuthu, M., Jing, Ch., Gie, L., Mun, L., \& Ping, T. (2010). Islamic banking: selection criteria and implications. Global Journal of Human Social Science, 10(4), 52-62.

Metawa, S., \& Almossawi, M. (1998). Banking behavior of Islamic bank customers: perspectives and 
implications. International Journal of Bank Marketing, 16(7), 299-313.

Mirza, A., \& Riaz, S. (2012). Training needs assessment in Islamic banking sector. Qualitative Research in Financial Markets, 4(2/3), 142-155. http://dx.doi.org/10.1108/17554171211252484

Naser, K., Ahmad, J., \& Al-Khatib, K. (1999). Islamic banking: A study of customer satisfaction and preferences in Jordan. International Journal of Bank Marketing, 17(3), 135-147.

Naser, K., Al Salem, A., \& Nuseibeh, R. (2013). Customers awareness and satisfaction of Islamic banking products and services: Evidence from the Kuwait Finance House (Note 1). International Journal of Marketing Studies, 5(6), 185-199. http://dx.doi.org/10.5539/ijms.v5n6p185

Nawi, F., Yazid, A., \& Mohammed, M. (2013). A critical literature review for Islamic banks selection criteria in Malaysia. International Business Research, 6(6), 143-151.

Ramadan, Z. (2013). Jordanian criteria for Islamic banks selection. Evidence from the Jordanian banking sector. International Journal of Academic Research in Accounting, Finance and Management Sciences, 3(3), 139-145.

Ramdhony, D. (2013). Islamic banking awareness attitudes and bank selection criteria. International Journal of Humanities and Applied Sciences, 2(2), 29-35.

Rashid, M., \& Hassan, M. (2009). Customer demographics affecting bank selection criteria, preference, and market segmentation: Study on domestic Islamic banks in Bangladesh. International Journal of Business and Management, 4(6), 131-146.

Rashid, M., Hassan, M., \& Ahmad, A. (2009). Quality perception of the customers towards domestic Islamic banks in Bangladesh. Journal of Islamic Economics, Banking and Finance, 5(1), 109-131.

Rehman, A., \& Masood, A. (2012). Why do customers patronize Islamic banks? A case study of Pakistan. Qualitative Research in Financial Markets, 4(2/3), 130-141.

Riggall, J. (1980). A new study: How newcomers select banks. ABA Journal, 93-94.

Saleh, M., Rosman, M., \& Nani, N. (2013). Bank selection criteria in a customers' perspective. Journal of Business and Management, 7(6), 15-20.

Sayani, H., \& Miniaoui, H. (2013). Determinants of bank selection in the United Arab Emirates. International Journal of Bank Marketing, 31(3), 206-228. http://dx.doi.org/10.1108/02652321311315302

Selamat, Z., \& Abdul-Kadir, H. (2012). Patronage factors of bank customers in Malaysia: Muslim and non-Muslim views. Journal of Islamic Economics, Banking and Finance, 8(4), 87-100.

Tara, N., Irshad, M., Khan, M., \& Yamin, M. (2014). Factors influencing adoption of Islamic banking: A study from Pakistan. Journal of Public Administration and Governance, 4(3), 352-367. http://dx.doi.org/10.5296/jpag.v4i3.6677

Zaher, T., \& Hassan, K., (2001). A comparative Literature survey of Islamic Finance and Banking. Institutions and Instruments, 10(4), 155-199.

Zulfiqar, B., Arshad, H., Fareed, Z., Shahzad, F., \& Hussain, Sh. (2014). Criteria of selecting bank in Pakistani banking sector: Study of banking customers in Sahiwal, Pakistan. International Journal of Managing Value and Supply Chains, 5(4), 19-31.

\section{Notes}

Note 1. USA: Kaufman, 1967; Riggall 1980. Jordan: Erol and El-Bdour, 1989; Erol et al., 1990; Naser et al., 1999; Ramadan, 2013. Turkey: Kaynak et al., 1991. Malaysia: Haron et al., 1994; Ahmad and Haron, 2002; Dusuki and Abdullah, 2007; Amin, 2008; Haque et al., 2009; Marimuthu et al., 2010; Loo, 2010; Doraisamy et al., 2011; Selamat and Abdul-Kadir, 2012; Abduh and Omar, 2012; Saleh et al., 2013; Nawi et al., 2013; Ismail et al., 2014. Bangladesh: Rashid and Hassan, 2009; Rashid et al., 2009. Pakistan: Awan and Bukhari, 2011; Hamid and Masood, 2011; Rehman and Masood, 2012; Khan, 2012; Hasan et al., 2012; Imtiaz et al., 2013; Zulfiqar et al., 2014; Awan and Azhar, 2014; Tara et al., 2014.Tunisia: Chebab and Zribi, 2012. Nigeria: Abiah and Wabekwa, 2012; Chikezie and Nwukamaka, 2014. Mauritius: Ramdhony, 2013.

Note 2. The main reason for determining the Cronbach's alpha is to test the reliability of the participants' answers to all sections of the questionnaire, rather than specific sections of the questionnaire. 


\section{Copyrights}

Copyright for this article is retained by the author(s), with first publication rights granted to the journal.

This is an open-access article distributed under the terms and conditions of the Creative Commons Attribution license (http://creativecommons.org/licenses/by/4.0/). 